\title{
Re-Reading an Architecture Text via Rhetoric: Suleymaniye Mosque Narrative in Tezkiretu'l- Bunyan
}

\author{
By Serap Durmus* \\ Hatice Genccan ${ }^{\dagger}$
}

This paper, intends to propose the textual representations of architecture for the agenda, is mentioned Süleymaniye Mosque narrative in Tezkiretü'l-Bünyân (The Record of Construction) which is a crucial manuscript of Ottoman writing tradition. With this purpose, a re-reading method is tried via rhetoric art that involves the meanings of effective speaking, writing and persuasion in this text analysis. Rhetoric's imagery term, that means imagination, image, imitation, description and definition, is chosen as a tool in re-reading method. Tezkiretü'l-Bünyân as a case of this paper includes significant presumptions, which are belonging to Ottoman architecture literature and intelligence. Tezkiretü'l-Bünyân consists of six buildings of Architect Sinan and also is a complete narrative of Sinan's life and buildings. Therefore, this paper analyses the Süleymaniye Mosque narrative via rhetoric as an example of re-reading the architecture texts. So the subject analysis aims to resettle an architecture text to the agenda of readers and to rethink the connection of text and rhetoric.

\section{Introduction}

Certainly texts provide the material for any research, which intend to establish the relationship between the thought and literature of architecture. Indeed, the texts also provide the most important basis and source of the theoretical representations of architecture. At a time when the borders of architecture as a discipline are probed on a daily basis, the studies to re-read/ reinterpret architecture as an alternative perspective to its discourse and investigative capabilities are on the agenda.

In the domain of architecture, re-reading arises frequently as a popular and new form or technique of knowledge production in contemporary literature. Re-reading, given the interdisciplinary nature of its elements, and the relationship it establishes with literary arts, has gradually developed into a practice of attaching meaning that can be exercised in architecture as well. Assuming that the theoretical aspect of architecture is about forming a narrative, the links established between the discipline of architecture on the one side, and literature and linguistics on the other, become even more meaningful.

A glance at the linguistics studies dating back to Ferdinand de Saussure's ${ }^{1}$ works reveals that the arbitrariness of the relationship between the word and

\footnotetext{
* Assistant Professor, Karadeniz Technical University, Turkey.

${ }^{\dagger}$ Master Student, Karadeniz Technical University, Turkey.

1. F. Saussure, Genel Dilbilim Dersleri (İstanbul: Multilingual Publishing, 2001). 
the meaning can be associated with the literary state of the explicitness and implicitness of the meaning. Saussure and other linguistics building on and expanding his work defined language as a series of pointers denoting various concepts. Interpreting a discipline, philosophy, structure, text, word, and so on through a distinctive and unique perspective is actually a case of deconstructivist reading. The deconstructivist reading paradigm suggests a wealth of knowledge, which enables making sense of the past, through diverse conceptual infrastructures and cognitive patterns. That is why deconstruction is a method of inquiry, which lays down conditions amenable to re-reading. ${ }^{2}$ In particular, the efforts to re-read and reinterpret within the framework of the disciplines of literary arts, history and philosophy are built around the reconstruction of texts. Because re-reading intends to move target the meaning hidden in the depths of the text.

One should note that different perspectives are required for writings on architecture as a field of re-reading. Rhetoric, as the art of persuasion and eloquence can present itself as a crucial means to decipher a text and to interpret the symbolic language used therein. In this study, on the other hand, rhetoric is used as a means to interpret the language used in the text of Tezkiretü'l-Bünyân, an important example of the textual representation of Ottoman architecture, from the perspective of architecture with reference to the narrative on Süleymaniye Mosque.

\section{Rhetoric as a Thinking Tool: The Text and Architecture Relation}

The re-reading efforts arguably serve producing new knowledge, and remembering and bringing into focus what is forgotten, all through a new perspective. Re-reading through rhetoric, on the other hand, signify the potential using textual research materials as a welcome extension to the usual field of application of rhetoric-verbal discourse. In this sense, rhetoric offers the potential and depth required of a tool to establish the relationship between text and architecture, and can become a piece of literary symbolism as a discipline (or interdisciplinary nature thereof). This is the point where definitions of rhetoric are to be discussed, followed by a few words on its existence as a means.

According to Plato ${ }^{3}$ rhetoric is defined as an art to persuade/convince/and of eloquence. It is also possible to define rhetoric as a means to communication between two parties, an activity to transfer knowledge. At times, rhetoric is used as a form of speech; at others it provides a form of discussion. Another definition of the term rhetoric is about the art of using language for convincing others, for reasoning, and for persuasion. ${ }^{4}$ Rhetoric tries to establish a balance between the form and essence, while keeping an eye on how a discourse is laid, and what is being told.

In addition to the five primary canons of rhetoric-invention, arrangement,

2. S. Durmus and S. O. Gur, "Rhetoric Reading in Architecture: A Methodology Attempt," The Journal of International Social Research 7, no. 31 (2014): 48-488.

3. Platon, Gorgias (trans.) Reyan Erben (İstanbul: M.E.B. Publishing, 1997), 453-E.

4. S. E. Ulas, Felsefe Sözlüğ̈̈ (ed.) A. B. Güçü vd (Ankara: Bilim ve Sanat Publishing, 2002). 
style, memory, delivery-, there are certain terms/concepts which serve or which enable the maintenance of rhetoric. ${ }^{5}$ It is widely known that concepts have not only a primary definition, but also secondary or metaphorical meanings. On the other hand, the concepts can be expanded through secondary concepts, which comprise, suggest, or evolve on the primary concept. While concepts can serve as the rhetoric of expressing others, they can also directly function as means of an analysis.

The text Tezkiretü'l-Bünyân covered in this study serves as the primary material of the analysis carried out for rhetorical purposes. ${ }^{6}$ Imagery was chosen as the term/concept of rhetoric deemed applicable for this specific text, which provides a glance at the textual realm of the Ottomans. Through the process signifying a transition from expression, statement, or meaning (denotation) to imagination, images, vision, approximation, description, or definition (imagery) in the glossary of rhetorical terms, the latter concept of imagery occupies a central position regarding rhetoric in terms of making textual expression visible.

In rhetoric, the term imagery, refers to a metaphorical language used to characterize sensory details and emotions or to represent abstractions. At a physical and concrete level, imagery is related with five senses. At an expanded and deepened level, on the other hand, an image may represent much more than what the initial perception reveals. For instance, an author may utilize a complex image alongside the metaphors and analogies as elements of speech. Rhetoric and analogy/comparison, which is covered by hermeneutics, occupy a crucial position in enabling the reader to visualize the image she heard of during the speech, with reference to the wealth of meaning.

Keating and Levy ${ }^{7}$ discuss a number of criteria to enable the reader to interpret a literary text as a poem. Imagery is one of them. The authors define imagery as the poet's act of creating sensory impressions in the reader's mind, with a view to enabling the latter to imagine using all five senses ${ }^{8}$. That is why literary texts, which meet artistic criteria, can be deemed to have poetic characteristics. For instance Kant, ${ }^{9}$ in his book the 'Critique of Pure Reason' discusses the idea of 'synthesizing diversity through imagery'. Eco, on the other hand points out the reality of image presented through a new perspective, by arguing that a language based on images would usually be based on the impression that an image reflects the characteristics of the object referred to. In a more contemporary analysis, Ungers ${ }^{10}$ tried to interpret images through ideas, imagery,

5. These terms comprise a series often called the List of Rhetorical Terms or Glossary of Rhetorical Terms. The number of terms can vary from source to source.

6. S. M. Celebi, Yapılar Kitabl: Tezkiretü'l Bünyan ve Tezkiretü'l Ebniye (Mimar Sinan'ın Anıları) (ed.) Hayati Develi Samih Rifat and Arzu Karamani Pekin (İstanbul: Koç Kültür Sanat, 2002); H. Crane and E. Akin, Sinan's Autobiographies: A Critical Edition of Five Sixteenth-Century Texts (Leiden, Boston: Brill, 2006).

7. L. Keating and W. Levy, Lives Through Literature: A Thematic Anthology (Macmillan Pub Co, 1991).

8. A. Erden, Kısa Öyküde Şiirsellik Boyutu (2001).

9. I. Kant, Arı Usun Eleştirisi (trans.) Aziz Yardımlı (İstanbul: İdea Publishing, 1993), A95.

10. O. M. Ungers, Kent Metaforlart: Morphologie (trans.) Ceren Öztürkcan (İstanbul: Lemis Publishing, 2013). 
metaphors and analogies.

Imagery drew the interest of many authors, and lends its use as a rhetoric tool in re-reading an architecture text, given its ability to establish connections between the past, now and future at a cognitive level, as well as its inclusion of metaphors/analogies. In this context, any linguistic efforts to create a mental characterization of a description, definition, or narrative would naturally serve rhetoric. The persuasive element of the text of Tezkiretü'l-Bünyân can be read as an example of imagery, due to the expression it instills in the reader and its ability to stir the reader's senses.

\section{Literature on the Text of Tezkiretu'l-Bunyan}

Any author who embarks on a journey of writing on architecture, as well as any literary product which is a part of that journey, contributes significantly to the theory and literature of history. In the case of Ottoman literary production, on the other hand, one can safely argue that the authors of the day did not embark on a journey of historiography in the modern sense ${ }^{11}$. It is possible to argue that the Ottoman architecture community revealed a significant accumulation of knowledge given the wealth of its products, while the literature it left behind was far from accessible given the very limited number of theoretical sources it created.

The works, which are the most important theoretical sources in the quest to make sense of the Ottoman mindset, on the other hand, serve as rare and most crucial examples of this theoretical field. For instance Sâi Mustafa Çelebi's ${ }^{12}$ surviving works Tezkiretü'l-Bünyan (Record of Construction) and Tezkiretü'lEbniye (Record of Buildings) which were published as 'Yapılar Kitabi'13 providing the facsimile of the Ottoman language original and its transliteration are among the leading examples in this context (Figure 1). Furthermore Tuhfetü'l-mi'mârîn (Choice Gift of the Architects), er-Risâletü'l-Mi'mâriyye (Treatise on Architecture) and Adstz Risâle (Untitled Treatise) are unique manuscripts and are among major pieces discussing Ottoman architectural historiography.

11. O. I. Tuluk, "Gerçekle Mit Arasında Mimar Sinan: Sinan Üzerine Bir Yeniden Okuma Denemesi," Mimarlık Journal 377 (TMMOB, Ankara, 2014): 65-69.

12. The English language text of Tezkiretü'l-Bünyan reviewed in this study was provided by Howard Crane and Esra Akcan, in the book Sinan's Autobiographies: A Critical Edition of Five Sixteenth-Century Texts (2006).

13. Celebi, Yapılar Kitabı: Tezkiretü'l Bünyan ve Tezkiretü'l Ebniye (Mimar Sinan'ın Anılarl), 2002. 

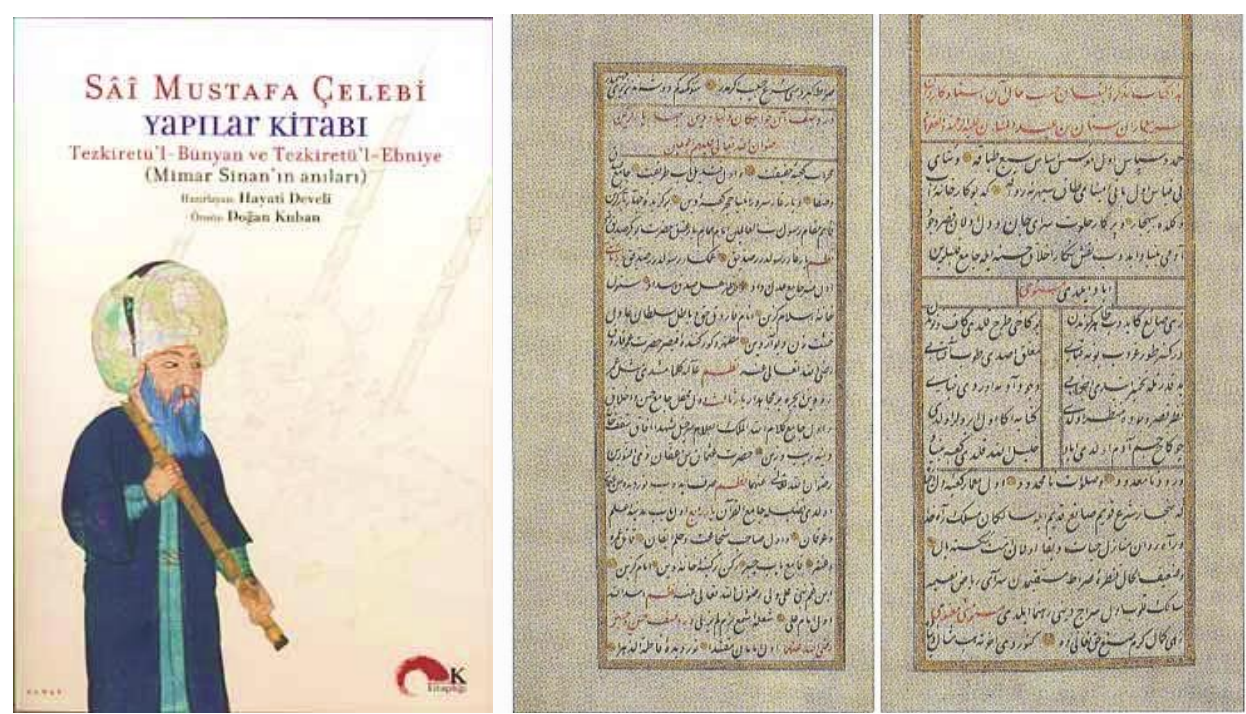

Figures 1 and 2. Sâi Mustafa Çelebi's Book of Buildings (Yapılar Kitabı); The First Two Pages of Tezkiretü'l-Bünyan (TSMK, Revan Köşü̈, nr. 1456) (Saatçi, 2008: 540)

These specimens are actually literary representations of the knowledge of Sinan the Architect, and are invaluable given the stories they contain. ${ }^{14}$ Tezkiretü'l-Bünyan, a $16^{\text {th }}$ century text, on the other hand is considered a collection of stories penned by Sâî Mustafa Çelebi, ${ }^{15}$ containing actual quotes heard from Sinan the Architect in his old age, about his life and the narrative of his buildings. ${ }^{16}$ In support of this piece of information is the statement in Tezkiretü'l-Bünyan's introductory section titled 'Introduction to Pleasing Text without Parallel", noting that the text was authored by Sâî Mustafa, and was based on his conversations with Sinan. ${ }^{17}$

The leading collection of accounts about Sinan the Architect, Tezkiretü'lBünyan, contains Sinan's memories as a biographical work telling about six construction projects ${ }^{18}$ (Figure 2).

14. Tuluk, "Gerçekle Mit Arasında Mimar Sinan: Sinan Üzerine Bir Yeniden Okuma Denemesi," 2014.

15. S. B. Morkoç, A Study of Ottoman Narratives on Architecture: Text, Context and Hermeneutics (Bethesda-Dublin-Palo Alto: Academia Press, 2010), 35. He cites that, Sâî Mustafa Çelebi was a famous poet, a painter, an illuminator and a stonemason according to Franz Babinger.

16. Crane and Akin, Sinan's Autobiographies: A Critical Edition of Five Sixteenth-Century Texts; Morkoç, A Study of Ottoman Narratives on Architecture: Text, Context and Hermeneutics; Tuluk, "Gerçekle Mit Arasında Mimar Sinan: Sinan Üzerine Bir Yeniden Okuma Denemesi". Texts, 9.

17. Crane and Akin, Sinan's Autobiographies: A Critical Edition of Five Sixteenth-Century

18. A. Kuran, "Mimar Sinan'ın Eserleri ve Camileri Konusunda Kısa Bir Değerlendirme," Boğaziçi University Journal Dergisi 4-5, no. 1030 (1976-1977): 83-101; S. Saatçi and M. Sözen. Mimar Sinan and Tezkiretü'l-Bünyan (Istanbul: MTV Publications, 1989); G. Tümer, “İki Osmanlı Klâsiği: "Tezkiretü’l-Bünyan” ve "Tezkiretü’l-Ebniye”" Mimarllk Journal 311. TMMOB, Ankara (2003); G. Necipoğlu, The Age of Sinan: Architectural Culture in the Ottoman Empire (Princeton and Oxford: Princeton University Press, 2005); Crane and Akin, Sinan's Autobiographies: A Critical Edition of Five Sixteenth-Century Texts; Morkoç, A Study 
As it relates the key events Sinan witnessed during his extended career, Tezkiretü'l-Bünyan provides the reader with, according to many historians of architecture, crucial details on the life and work of Sinan and the period he lived in. ${ }^{19}$ Yet, there is not an overwhelming consensus on this point. For instance Kuban notes that all the stories related in the text had been fabrications and statements by Sâî Mustafa Çelebi, who tried to praise the great architect as an encomium. ${ }^{20}$ For Kuban has doubts about the actual source of the narratives, with specific reference to Tezkiretü'l-Bünyan and Tezkiretü'l-Ebniye, stating that the textual characteristics of Ottoman narratives on architecture reveals a confusion as such texts usually lie on the limbo between history and literature. ${ }^{21}$

Crane and Akın have identified eleven distinct versions of Tezkiretü'lBünyan. ${ }^{22}$ Ten of these are manuscripts, whereas one is a printed edition. A few words on the contents of the text would note that Tezkiretü'l-Bünyan, which is characterized by a few poems thrown here and there through the flow of the actual text, starts with encomia. That introduction is then followed by the "Complaint against the Age" passage expressed as a poem. The three sections titled "The Characteristics of Sublime Buildings", "The Reason This Humble Servant Was Appointed Architect to Build Unequaled Warships in the Field of Battle", and "Concerning the Campaign against the Unbelievers and How the Humble Servant Became an Architect", to follow, on the other hand, contain stories about the early career of Sinan. ${ }^{23}$

Six subsequent sections, which make up the larger part of the text, also contain details and remarks regarding the construction of major building projects implemented by Sinan. The sections laying down the foundations of the text are "Concerning the Paradiselike Edifice of Şehzade Sultan Mehmed Khan", "Concerning the Construction of the Heaven-Resembling Arches of That Brings Flowing Water to the Admired Fountains of the City of Istanbul", "The Aspects of the Construction of the Friday Mosque of Sultan Süleyman Khan Built in the City of Istanbul with Perfect Care", "Concerning the Construction, with the help of God, the Lord, the Pardoner, of the Well of the Waterwheel of the Garden of the Prosperous Padishah", "Concerning the Beautiful Bridge of Çekmece-i Kebir of the Reign of Sultan Süleyman Khan-May God's Mercy and Blessing Be upon Him!" and "The Commencement of the Construction of the Noble Friday Mosque of Sultan Selim Khan".24

The Süleymaniye Mosque narrative to be discussed in this study, on the

of Ottoman Narratives on Architecture: Text, Context and Hermeneutics; Tuluk, "Gerçekle Mit Arasında Mimar Sinan: Sinan Üzerine Bir Yeniden Okuma Denemesi”.

19. Morkoç, A Study of Ottoman Narratives on Architecture: Text, Context and Hermeneutics.

20. D. Kuban, "Preface to Sai Mustafa Celebi," in Yapllar Kitabl: Tezkiretü'l Bünyan ve Tezkiretü'l Ebniye, (Mimar Sinan'ın Anıları.) (ed.) Hayati Develi Samih Rifat and Arzu Karamani Pekin (İstanbul: Koç Kültür Sanat, 2002), 7-8; Morkoç, A Study of Ottoman Narratives on Architecture: Text, Context and Hermeneutics.

21. Morkoç, A Study of Ottoman Narratives on Architecture: Text, Context and Hermeneutics.

22. Crane and Akin, Sinan's Autobiographies: A Critical Edition of Five Sixteenth-Century Texts.

23. Ibid.

24. Ibid, 6-8. 
other hand, comprises the third of six monumental works discussed in Tezkiretü'l-Bünyan. "The Aspects of the Construction of the Friday Mosque of Sultan Süleyman Khan Built in the City of Istanbul with Perfect Care" narrative discusses the construction of the Süleymaniye Mosque. This section describes the commencement of the construction of the mosque, and how the characteristic marble columns were gathered from various corners of the Ottoman world. ${ }^{25}$ The narrative starts with the decision regarding the location to build the mosque on, and proceeds on a logical order with the fetching of the columns, commencement of construction and completion of the works. In the light of all these pieces of information, one can safely argue that the strong analogies and stories in Tezkiretü'l-Bünyan are crucial in terms of deciphering the rich rhetoric of the narrative.

\section{Re-Reading Suleymaniye Mosque Narrative over Text}

Re-reading activities investigate interpretive perspective opportunities with reference to the new pieces of information they produce. As an image lending itself to textual internalization in addition to physical existence, the narrative of Süleymaniye Mosque is a major Ottoman literary presentation with the potential to offer a wealth of meaning to its readers, in the form of Tezkiretü'l-Bünyan.

In the re-reading which is effected over the rhetoric and which investigates the meaning capabilities, the concept of imagery serving rhetoric was adopted as a tool. In the narratives where imagery is observed, various architectural elements were emphasized through analogies and metaphors. The tables thus drawn up include narratives where the text is deemed to have served rhetoric, as well as drawings of the architectural elements of Süleymaniye Mosque. With a view to making the text easier to follow on part of the reader, the original flow of the narrative on Süleymaniye Mosque within the overall text of Tezkiretü'l-Bünyan was preserved; the quotations included in the text follow the order of the original.

The following narrative on the development of the idea of building a mosque in the mind of Suleiman the Magnificent, and on the appointment of the architect, was provided in the words of Sinan the Architect. Descriptive phrases such as 'the rising sun' or 'a blessed day' emphasizes the fact that the time frame between the rise of the first idea and the implementation per se was very brief:

"One morning, the idea of setting about the construction of an exalted Friday mosque entered noble, auspicious heart of that sun of knowledge and beloved of the hearts of men and jinns, His Majesty, the fortunate padishah, the late and forgiven Sultan Süleyman Khan son of Selim Khanmay God's mercy and pardon be upon him. He summoned his servant, this

25. Ibid; Morkoç, A Study of Ottoman Narratives on Architecture: Text, Context and Hermeneutics. 
weak slave, the architect Sinan son of 'Abdülmennan, to consult about the noble mosque, and the design of the building was settled upon and its location determined. Then, at an esteemed time and a fortunate and auspicious hour, the foundations of that exalted Friday mosque were laid, sacrifices were made, and its construction was begun with [the distribution of] endless gifts and favors to the poor and upright." 26

Süleymaniye Mosque's four columns, which are known to have been expropriated from other works are described in detail in the text, and the process of their gathering and installation is discussed extensively. According to the text, each of the four large columns to be used in the construction of the mosque represent one person. The column, which draws most attention due to its size as well as name, on the other hand, is understood to be 'Kıztaş1'. This section, which provides information on the construction process arguably, has an impassioned narrative style. The metaphor of a rope as wide as a human torso, as well as animated descriptions such as the introduction of the columns to the construction site with sounds indicate a type of imagery that appeals to the emotions of the reader (Table 1):

"In the fiest place, each of those four marble columns, which are emblems of the four Chosen Friends, is like a stately cypress of the garden of the faith. Each of them came from a [different] land. One of those columns was erected by a maiden in the time of the unbelievers in the district called Kıztaşı. Known as the Maiden's Column (Kıztaşl), it was like a monolithic minaret and the trunk of the Tuba tree... In sum up, upon the imperial command of the Padishah, refuge of the universe, we erected the masts of great galleons and built a strong scaffolding story by story. And we collected massive lighter cables in one place and bound them with hawsers thick as a man's body to iron pulley blocks. And, in the place where it stood, we firmly bound the entire shaft of the above-mentioned column with galley masts, and attached those ships' cables thick as a man's body to the steel blocks in two places... Many thousand novices (acemioğlan) entered the treadmill, and thousands of the demons of Solomon from among the Frankish prisoners shouted all together, "Heave ho!" and attached a strong reserve [cable] to the above-mentioned cables. And, when, with [shouts of] "God! God!" they uprooted the above-mentioned column that was like the axis of the celestial sphere, sparks were scattered from the blocks like lightning... Then the demons of Solomn mounted [the column] on boat chocks and brought it to the noble building. By order of the shah, the excess [of the column] was cut down, and it became uniform with the other columns. And they brought one of its columns from Alexandria with a barge. And they transported another of its columns down to the seashore from Ba'albek and brought it by barge. And yet

26. Crane and Akin, Sinan's Autobiographies: A Critical Edition of Five Sixteenth-Century Texts, 122. 
another column was found standing ready in the imperial palace.,27

Table 1. Imagery-Rhetoric Relation of Tezkiretü'l-Bünyan Text: Column

\begin{tabular}{|c|c|c|}
\hline \multicolumn{3}{|c|}{ SÜLEYMANIYE MOSQUE, Istanbul, Turkey } \\
\hline $\begin{array}{c}\text { Architectural } \\
\text { Element }\end{array}$ & $\begin{array}{c}\text { Imagery } \\
\text {-Cypress of the } \\
\text { garden of the } \\
\text { faith } \\
\text {-Monolithic } \\
\text { minaret } \\
\text {-The Trunk of the } \\
\text { Tuba tree }\end{array}$ & $\begin{array}{c}\text { Rhetoric of Tezkiretü'l-Bünyân } \\
\text { "... each of those four marble columns, which } \\
\text { are emblems of the four Chosen Friends, is like a } \\
\text { stately cypress of the garden of the faith. Each of } \\
\text { them came from a [different] land...." }\end{array}$ \\
\hline
\end{tabular}

Source: Author, 2014.

Marble, one of the defining construction materials of the classical age ${ }^{28}$ have found its way to the narrative on Süleymaniye Mosque. The procurement of the marbles to be used in the construction of the mosque, as well as their descriptions reinforced with analogies instill a poetic language in the narrative. The relationship between the material and the narrative is reinforced and animated with the help of a number of analogies:

"...And the white marbles were cut from the quarry on the island named Marmara, and the green marbles were from Arabia, and the porphyry medallions and panels, concerning which it would be right to say no equals exist in the World, are worthy and precious jewels whose quarry is not known. $" 29$

Süleymaniye Mosque has a total of eight gates; three in the courtyard and five in the main building. The text does not provide any reference to the number or size of the gates, yet discusses them with reference to their construction technique and ornamentation (Table 2). In this context, a narrative to serve concepts such as gift, uniqueness, perpetuity and eternity, as well as to describe the kündekâri and sedefkâri techniques makes itself felt:

27. Ibid, 123.

28. H. Önkal, Osmanlı Hanedan Türbeleri (Ankara: Ministry of Culture Publishing, 1992).

29. Crane and Akin, Sinan's Autobiographies: A Critical Edition of Five Sixteenth-Century Texts, 123. 
"And each of its artistically fashioned doors and wood-carved fittings filled with ornament and decoration of mother-of-pearl is like a leaf of the Erjeng, such that they are admired by the grandees of the time and esteemed by the people of all lands. And that canopy-shaded pulpit and pillared throne is a keepsake of a skillful master that stands as a model to the World. Among the revolving spheres its like has not been seen nor shall it be seen.",30

Table 2. Imagery-Rhetoric Relation of Tezkiretü'l-Bünyan Text: Door

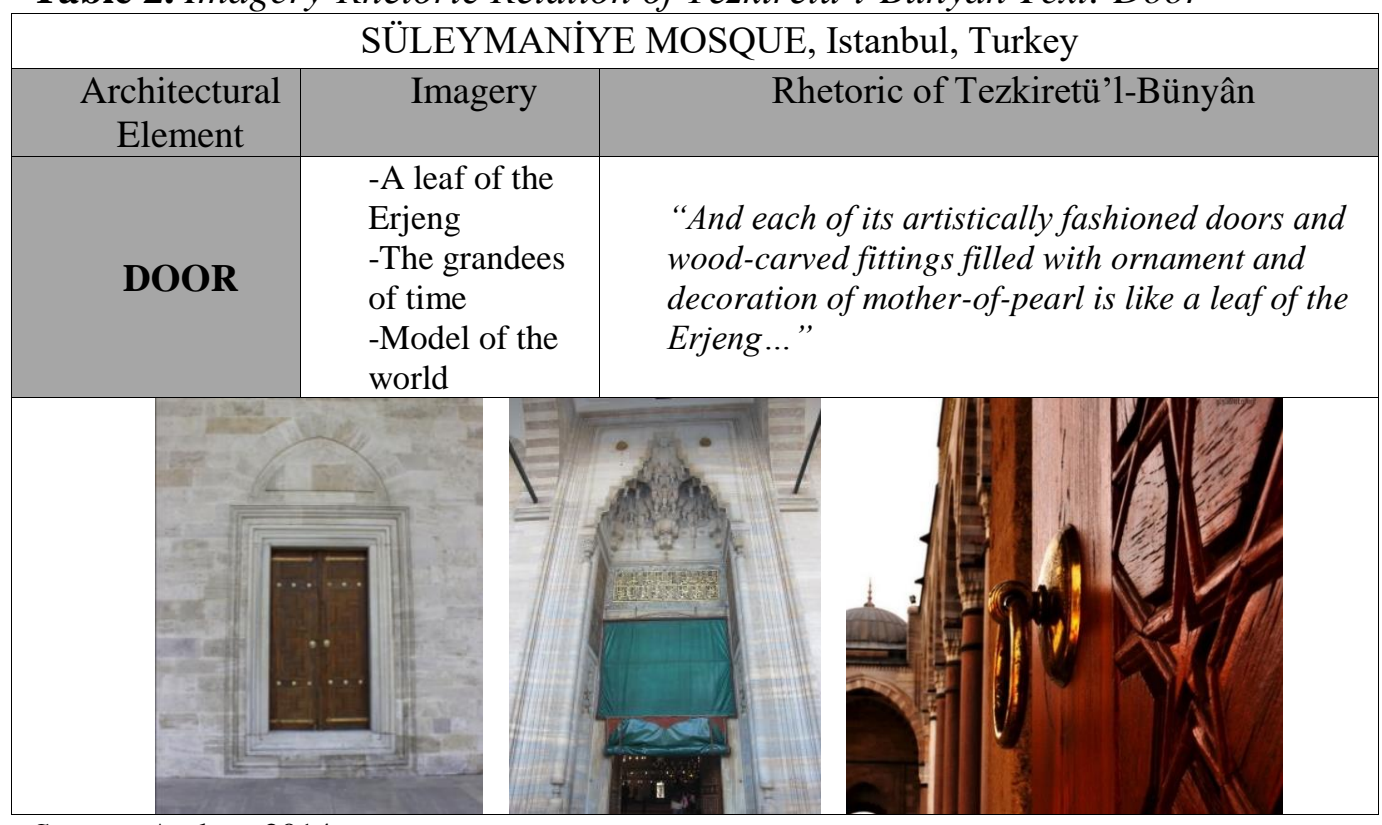

Source: Author, 2014.

The composition of the domes of Süleymaniye Mosque, one huge main dome and two semi-domes to surround it, accompanied by smaller domes, are discussed in the text through analogies with gold, waves, chameleons, rainbows, embroidery, and wings, with a view to reinforcing the meaning and vibe (Table 3). Two tall minarets with three balconies, adjoining the main volume, and two shorter minarets with two balconies next to the wall of the courtyard are mentioned in the text with reference to the prophet and his Four Friends (Table 4). The text does not note the number and shapes of the windows, yet contains analogies with reference to stained glasses. This approach leads the reader to imagining stained glasses, rather than thinking about the size and shape of a window (Table 5):

30. Ibid, 124. 
Table 3. Imagery-Rhetoric Relation of Tezkiretü'l-Bünyan Text: Dome-Semidome

\begin{tabular}{|c|c|c|c|}
\hline $\begin{array}{c}\text { Architectural } \\
\text { Element }\end{array}$ & $\begin{array}{c}\text { ImäLery } \\
\text { DOME }\end{array}$ & $\begin{array}{l}\text {-The bubbles } \\
\text { of the sea of } \\
\text { elegance } \\
\text {-Brilliant, } \\
\text { gleaming sun }\end{array}$ & $\begin{array}{l}\text { Rhetoric of Tezkiretü'l-Bünyân } \\
\text { "... the domes of that noble Friday mosque are } \\
\text { elegance, and its highest dome is like the } \\
\text { revolving heavens.." }\end{array}$ \\
\hline & &
\end{tabular}

Source: Author, 2014.

Table 4. Imagery-Rhetoric Relation of Tezkiretü'l-Bünyan Text: Minaret

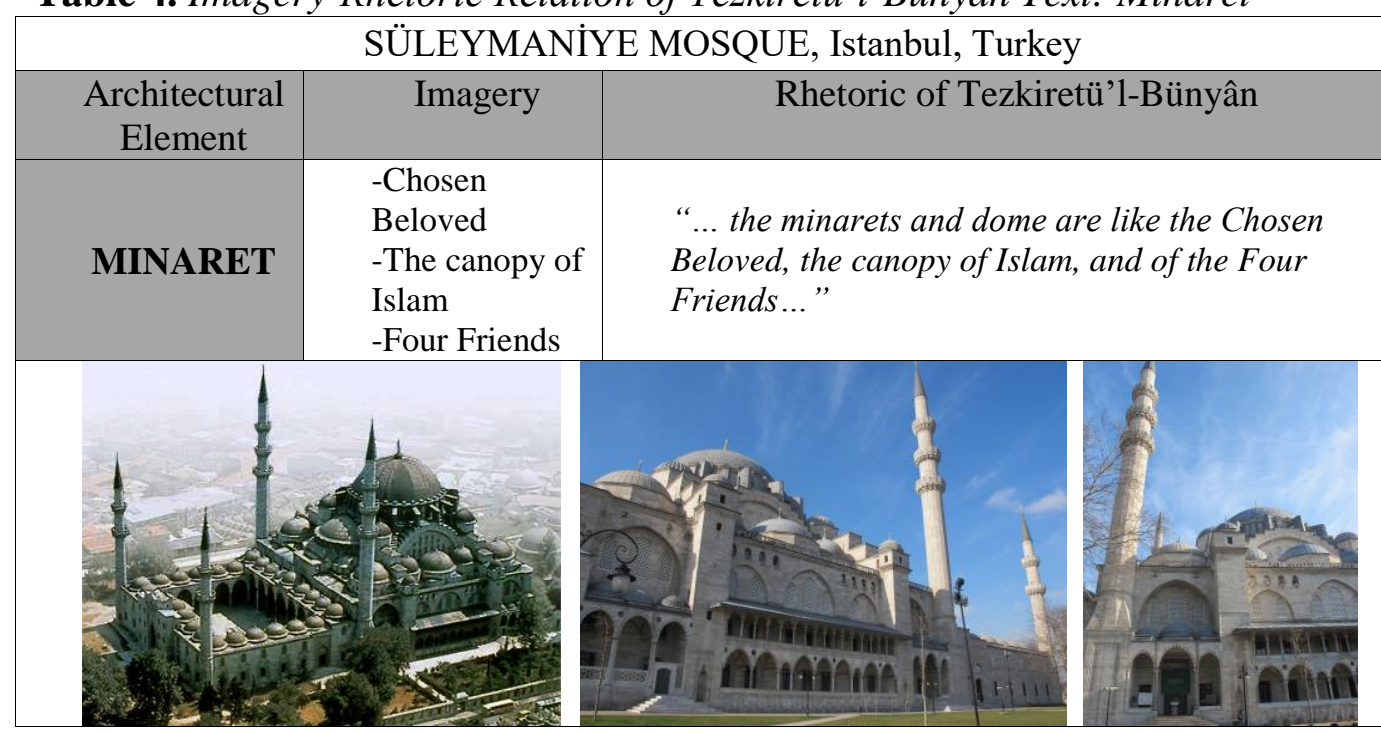

Source: Author, 2014.

"And the domes of that noble Friday mosque are ornaments like the bubbles of the sea of elegance, and its highest dome is like the revolving heavens. And the golden finial shining upon it is like the brilliant, gleaming sun. And the minarets and dome are like the Chosen Beloved, the canopy of Islam, and of the Four Friends. And the ornamented Windows, which are without like or equal, resemble the wings of Gabriel. When they are illumined with the sun's radiance, they are like an embellished rose garden of the springtime, and the rays of the azure vault reveal their cameleon-like iridescent designs. Ruby, cinnabar, lapis and verdigris were lavished on this transcendent exemplar of ornament and design, and beautiful, heartattracting designs were fashioned, the elegance of which confounds the 
eyes of those endowed with sight. ,"31

Table 5. Imagery-Rhetoric Relation of Tezkiretü'l-Bünyan Text: Window

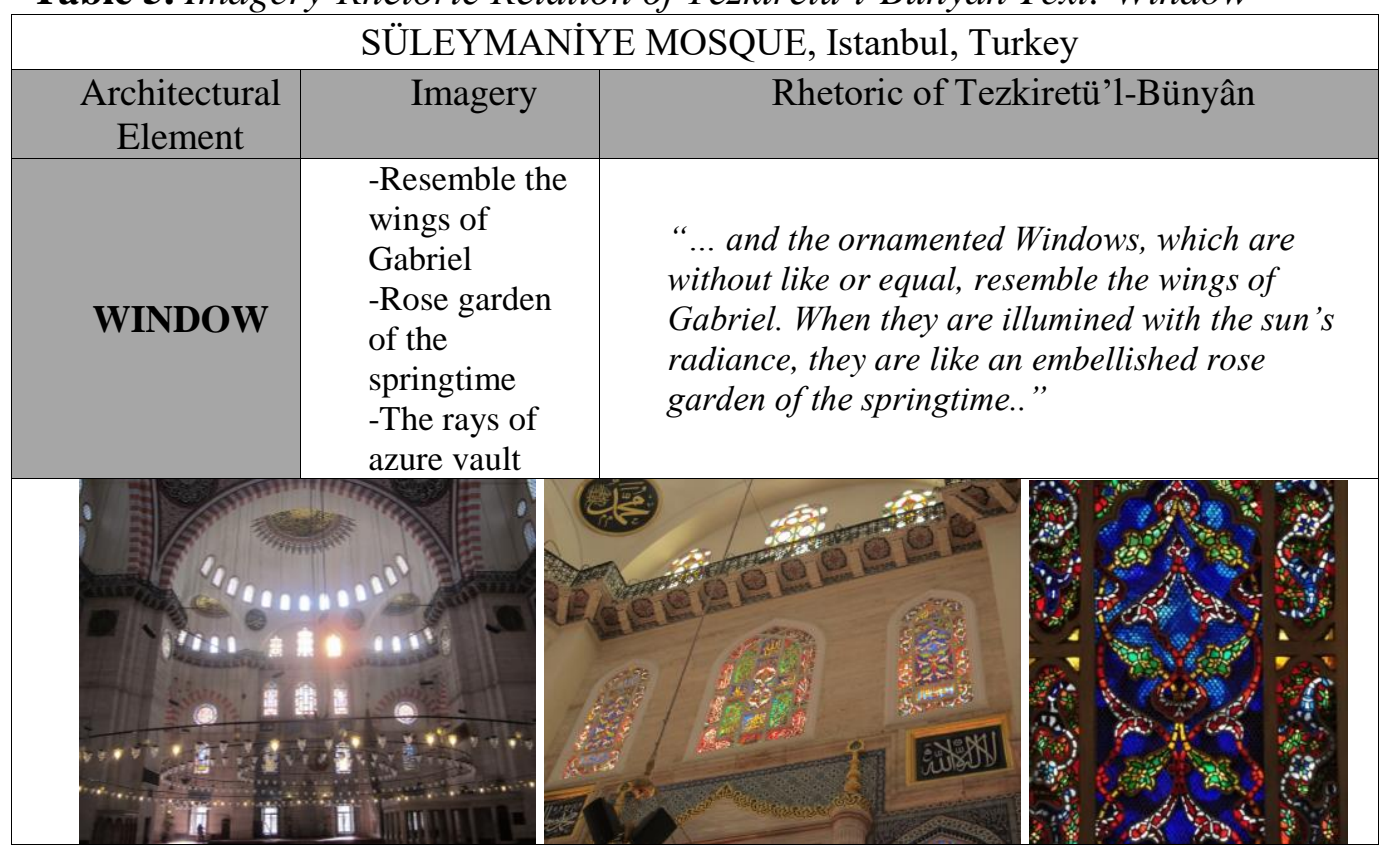

Source: Author, 2014.

There are eight inscriptions of Süleymaniye Mosque; one over each gate. The text discusses the superior qualities of the scripts to adorn the inscriptions, and supports them with analogies about the idea of permanence and leaving one's mark for the posterity. The involvement of excellent masters of inscription in the scripts in the interior of the domes, as well as the inscriptions over the gates, is particularly emphasized (Table 6):

31. Ibid. 
Table 6. Imagery-Rhetoric Relation of Tezkiretü'l-Bünyan Text: Script-Inscription

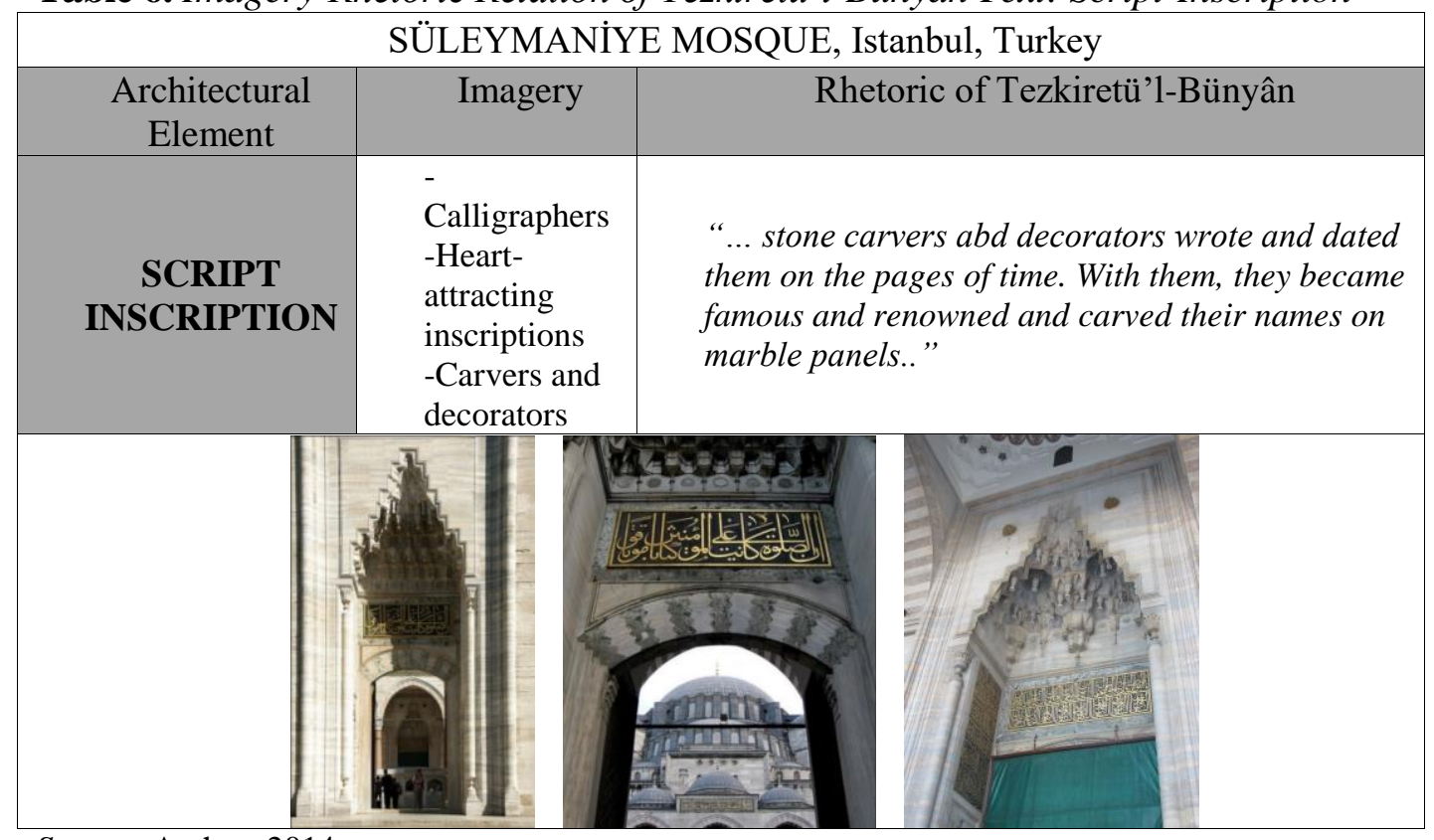

Source: Author, 2014.

When the beautiful dome of the noble Friday mosque was closed and the construction of the other parts was completed, the late pole of the calligraphers, Hasan Karahisari, inscribed in majuscule script (hatt-l müsenna) on the heavenly dome the entire noble verse "God holds the heavens and the earth". And he sought out suitable [texts] fort he inscriptions of each of its paradise-like doors and wrote many heart-attracting inscriptions. And stone carvers abd decorators wrote and dated them on the pages of time. With them, they became famous and renowned and carved their names on marble panels. "32

The following passage, where the architect ruminates about the issues he faced, relays the complaints and some memories regarding the construction of the mosque. The architect's admiration for the dome, on the other hand, is noted with emphasis on the dome as a sight for sore eyes:

"And when the felicitous Padishah was in Edirne the palace of Ferhad Pasha was built. Duplicitous people maliciously conspired to write [the sultan] that all of the supervisors and clerks had repaired their own houses under the pretext of the building [of the mosque], and fort hat reason completion of the mosque had been delayed. And they said that the houses built at the time of [its] contruction were dependencies of the noble Friday mosque: "Questions concerning this matter should be asked of the building supervisor." And, concerning this humble servant, they said, "He is not able to remove the scaffolding from the building because its defects would be revealed." And some fools said, "There is doubt whether the dome will stand

32. Ibid. 
up. The fellow is infatuated with it. He spends almost all his time [working on it]. He has no solutions. Obsessed with it, he has descended into the valley of madness. "33

The following quotation provided in the form of a dialog with the Sultan provides some information about the state of the mosque and defensive arguments about it. The story of the architect working on the construction of the mihrab and minbar while unaware of the developments outside his focus, relayed as a tale, offers a narrative weaker in imagery but stronger in narration compared to the other sections in other paragraphs:

"The felicitous padishah arrived while this humble servant, unware of the situation, was in the marble workers' workshop designing and laying out the noble mihrab and exalted minbar. I greeted him with politeness and waited at his service. With wrathful countenance, the late and forgiven [sultan] asked this weak and humble servant about the condition of that building and demanded, "Why do you not attend to this Friday mosque of mine and [instead] waste time on unimportant things? Is not the example of my fore-father Sultan Mehmed Khan's architect sufficient for you?" When will this building be completed? Speak up! Otherwise, you know [the consequences]!... Because I saw the anger, fury, and fulsome wrath in the Padishah, the refuge of the World, I, this weak ant, was dumbfounded and mute. Finally, with God's strength, this flowed from my lips without careful thought: "God willing, through the good fortune of my felicitous Padishah, it will be completed in two months... The late [sultan] called upon the agas present to witness [this statement] and said, "Well then, architect, if in two months it is not complete, we will be speaking to you!" and saying this he set off to the imperial palace. When he reached the palace, he declared to the hazinedarbass and other agas, "The architect's madness is obvious. Is it possible to complete many years' work in two months? The fellow has lost his mind out of fear for his head. Summon him and you, too, question him! See what answer he gives. If he speaks nonsense, the building's state will be in doubt!..." 34

After the dialog mentioned above, further dialogs and monologues are employed to relay the assignment of the workers in line with the promise to the Sultan, as well as the difficulties of the construction process:

When I answered thus, the agas again conveyed [my response] to the Padishah, refuge of the World, saying, "Felicitous padishah, the fellow is making great efforts. God willing, he is of sound mind. Given the care he lavishes [on it], it is hoped that it will be possible to perform prayer in your noble Friday mosque in the near future... And this humble servant exhorted all the idle and unemployed stonecutters and masons, installed

33. Ibid.

34. Ibid, 125. 
capable overseers, and, everywhere, contracted out to capable masters jobs that could be contracted... A week later, the felicitous sovereign again came to see the building. When he demanded, "Architect, do you still remain firm in your promise?" I said, "With the help of God, the Lord, the Pardoner, at the end of two months from that day I shall, with the favor of my felicitous Padishah, close completely the doors of the mosque and deliver the keys to your successful, noble hand... "35

The ceremony to submit the keys to the mosque, held once the building was completed and the Sultan arrived, was also shared with the readers. The sections regarding construction arguably have a more realistic style, while the descriptions of architectural elements make frequent use of analogies:

"I ceaselessly begged and beseeched God-glory be to Him and be He exalted-and morning and evening I fervently prayed fort he help of that Judge of humankind and said, ${ }^{, 36}$

The honor of opening the gate of the mosque was extended to the architect. The architect was also awarded with gifts and compliments to match the grandiose opening event. The following quotation provided as a dialog, offers rhetoric with the sufficient level of detail to enable the readers to imagine the awarding of the architect due to his efforts:

"Finally, at the end of two months, with the aid and favor of God-glory be to Him and be He exalted-and the zeal of the Padishah, not a detail remained undone, and, closing its door, the building was completely finished. One morning, like the sun that illumines the World, appeared, and I prayed and delivered up to his auspicious, noble hand the exalted key of the noble gate. With joy, I gave over the key to his blessed hand. I prayed and stood with hands clasped. The felicitous Padishah turned to the odabassl and asked, "Who would be most deserving and worthy of opening the gate of the Friday mosque?" The aforesaid replied, "My padishah, your slave the architect is a rare master. In this field he is a faithful servant, with the wisdom of Lokman... And with prayer and supplication he gave the key to this humble servant... In short, there is no end or limit to the favor and benevolence of that Padishah. May God, be He exalted, make prosperous his descendants and subjects in this World and the next and grant long life to the successor of Süleyman, Sultan Murad!',37

35. Ibid.

36. Ibid, 126.

37. Ibid. 


\section{Conclusions}

Every study serving the purpose of producing new information produces a new meaning. The meaning of the material used in the re-reading, on the other hand, stems from the subject who is actually reading the study. That is exactly the reason why we read each material again and again and attach meaning, regardless of the literary type and the source/author of the material. This is the essence of the deconstructivist reading which intends to offer an authentic perspective and which enables a fresh read. ${ }^{38}$

In this paper where the narrative on Süleymaniye Mosque provided in Tezkiretü'l-Bünyan, an analysis of the poetic side of Ottoman literary performance was provided with reference to the concept of imagery. The analysis arguably utilizes rich poetic analogies in the context of the Süleymaniye Mosque narrative in Tezkiretü'l-Bünyan. These analogies reinforcing the rhetoric of the narrative can help argue that the mosque is a place addressing the needs of the spirit, and offers an imagery to make the reader a part of heaven itself.

The comparison of the shape of domes with the bubbles in the sea, the texture of marbles with the beauty of the waves, as well as the connection between the main dome and four minarets and the prophet and his four friends, are just a few of the strong analogies referred to herein. ${ }^{39}$ In this context, it would not be off the mark to claim that the Süleymaniye Mosque narrative provides an example of rhetoric to reflect the concept of imagery. Because imagery intends to animate the feelings and to appeal to sensory details. It attaches importance to the language used.

In conclusion, it is clear that the text of Tezkiretü'l-Bünyan contains rich potentials of meaning and stories for the readers of architecture. The Ottoman literary style can be reflected once again by every author, through an interpretive perspective imposed by rhetoric. For the literary representation of architecture is as meaningful and possible as its concrete existence.

\section{Bibliography}

Celebi, S. M. Yapılar Kitabı: Tezkiretü’l Bünyan ve Tezkiretü'l Ebniye (Mimar Sinan'ın Anıları) [Book of Buildings: Tezkiretü'l Bünyan and Tezkiretü'l Ebniye (Architect Sinan's Memoirs.)] Edited by Hayati Develi Samih Rifat and Arzu Karamani Pekin. İstanbul: Koç Kültür Sanat, 2002.

Crane, H. and E. Akin. (ed.) Sinan's Autobiographies: A Critical Edition of Five Sixteenth-Century Texts. Leiden, Boston: Brill, 2006.

Durmus, S. and S. O. Gur. "Rhetoric Reading in Architecture: A Methodology Attempt." The Journal of International Social Research 7, no. 31 (2014): 48-488. http://bit. ly/2cvbreB.

38. U. Tanyeli, “Uğur Tanyeli ile Türkiye’de Mimarlık Tarihi Çalışmak ve Osmanlı Mimarlık Tarihyazımı," Türkiye Araştırmaları Literatür Dergisi 7, no. 13 (2009): 313-346.

39. Crane and Akin, Sinan's Autobiographies: A Critical Edition of Five Sixteenth-Century Texts; Morkoç, A Study of Ottoman Narratives on Architecture: Text, Context and Hermeneutics. 
Erden, A. Kısa Öyküde Şiirsellik Boyutu [The Dimension of Poetry in Short Story.] 2001. http://bit.ly/2c04YKg.

Kant, I. Arı Usun Eleştirisi [Critique of Pure Reason]. Translated by Aziz Yardımlı. İstanbul: İdea Publishing, 1993.

Keating, L. and W. Levy. Lives Through Literature: A Thematic Anthology. Macmillan Pub Co, 1991.

Kuban, D. "Preface to Sai Mustafa Celebi." In Yapılar Kitabı: Tezkiretü'l Bünyan ve Tezkiretü'l Ebniye, (Mimar Sinan'ın Anıları.) Edited by Hayati Develi Samih Rifat and Arzu Karamani Pekin. İstanbul: Koç Kültür Sanat, 2002, 7-8.

Kuran, A. "Mimar Sinan'ın Eserleri ve Camileri Konusunda Kısa Bir Değerlendirme" [A brief review of Mimar Sinan's works and mosques.] Boğaziçi University Journal Dergisi 4-5, no. 1030 (1976-1977): 83-101. http://bit.ly/2c05WWS.

Morkoç, S. B. A Study of Ottoman Narratives on Architecture: Text, Context and Hermeneutics. Bethesda-Dublin-Palo Alto: Academia Press, 2010.

Necipoğlu, G. The Age of Sinan: Architectural Culture in the Ottoman Empire. Princeton and Oxford: Princeton University Press, 2005.

Önkal, H. Osmanlı Hanedan Türbeleri [Ottoman Dynasty Tombs.] Ankara: Ministry of Culture Publishing, 1992.

Platon. Gorgias. Translated by Reyan Erben. İstanbul: M.E.B. Publishing, 1997.

Saatçi, S. and M. Sözen. Mimar Sinan and Tezkiretü'l-Bünyan. Istanbul: MTV Publications, 1989.

Saatçi, S. "Sâî Mustafa Çelebi encyclopedia article.” In İslam Ansiklopedisi 35 (2008): 539-541.

Saussure, F. Genel Dilbilim Dersleri [General Linguistics Courses.] İstanbul: Multilingual Publishing, 2001.

Tanyeli, U. "Uğur Tanyeli ile Türkiye'de Mimarlık Tarihi Çalışmak ve Osmanlı Mimarlık Tarihyazımı" [Interview with Uğur Tanyeli on Studying History of Architecture in Turkey and Historiography of Ottoman Architecture.] Türkiye Araştırmaları Literatür Dergisi 7, no. 13 (2009): 313-346.

Tuluk, Ö. İ. "Gerçekle Mit Arasında Mimar Sinan: Sinan Üzerine Bir Yeniden Okuma Denemesi" [A re-reading trial upon Sinan: Sinan the Architect in between the reality and myth.] Mimarlik Journal 377.TMMOB, Ankara (2014): 65-69. http:// bit.ly/2cHMOQc.

Tümer, G. "İki Osmanlı Klâsiği: "Tezkiretü'l-Bünyan" ve "Tezkiretü’l-Ebniye"” [Two Ottoman Classic: Tezkiretü'l-Bünyan and Tezkiretü'l-Ebniye.] Mimarlık Journal 311. TMMOB, Ankara (2003). http://bit.ly/2cDFVvb.

Ulas, S. E. Felsefe Sözlüğ̈̈ [The Dictionary of Philosophy.] Edited by A. B. Güçü vd. Ankara: Bilim ve Sanat Publishing, 2002.

Ungers, O. M. Kent Metaforlarl: Morphologie [Morphologie: City Metaphors]. Translated by Ceren Öztürkcan. İstanbul: Lemis Publishing, 2013. 
